\section{Elizabeth Fujimori'}

Ana Paula Sayuri Sato"

Sophia Cornbluth Szarfarc ${ }^{\text {III }}$

Gloria Valeria da Veiga ${ }^{\mathrm{IV}}$

Valterlinda Alves de Oliveira ${ }^{\vee}$

Célia Collivı

\section{Regilda Saraiva dos Reis Moreira-Araújo ${ }^{\mathrm{VII}}$}

Other authors are listed at the end of the article

Departamento de Enfermagem em Saúde Coletiva. Escola de Enfermagem (EE). Universidade de São Paulo (USP). São

Paulo, SP, Brasi

1" Programa de Pós-Graduação em Enfermagem. EE-USP. São Paulo, SP, Brasi

III Departamento de Nutrição. Faculdade de Saúde Pública. USP. São Paulo, SP, Brasil

Iv Departamento de Nutrição Social Aplicada. Instituto de Nutrição Josué de Castro. Universidade Federal do Rio de Janeiro. Rio de Janeiro, RJ, Brasil

Departamento de Ciência da Nutrição. Escola de Nutrição. Universidade Federal da Bahia. Salvador, BA, Brasil

v1 Departamento de Alimentos e Nutrição Experimental. Faculdade de Ciências Farmacêuticas. USP. São Paulo, SP, Brasil

vII Departamento de Nutrição. Centro de Ciências da Saúde (CCS). Universidade Federal do Piauí. Teresina, PI, Brasil

\section{Correspondence:}

Elizabeth Fujimori

Av. Dr. Enéas Carvalho Aguiar, 419

05403-000 São Paulo, SP, Brasil

E-mail: efujimor@usp.br

Received: 10/6/2010

Approved: 5/17/2011

Article available from: www.scielo.br/rsp

\section{Anemia in Brazilian pregnant women before and after flour fortification with iron}

\begin{abstract}
OBJECTIVE: To compare prevalence of anemia and hemoglobin $(\mathrm{Hb})$ levels in Brazilian pregnant women before and after flour fortification with iron.

METHODS: A repeated cross-sectional panel study of public health care centers of municipalities in the five Brazilian regions was conducted. Retrospective data were obtained from 12,119 medical records of pregnant women distributed in two groups: before fortification (delivery prior to June 2004) and after fortification (date of last period after June 2005). Anemia was defined as $\mathrm{Hb}<11.0 \mathrm{~g} / \mathrm{dl}$. Hb levels according to gestational age were assessed using two references from the literature. Statistical analysis was carried out using chi-squared tests, Student's t tests, and logistic regression, with a significance level of $5 \%$.
\end{abstract}

RESULTS: In the total sample, prevalence of anemia fell from $25 \%$ to $20 \%$ after fortification $(\mathrm{p}<0.001)$. However, important regional differences were evident: while significant reductions were seen in the Northeast (37\% to 29\%) and North ( $32 \%$ to $25 \%$ ) regions, where pre-fortification prevalence was high, smaller reductions were seen in the Southeast (18\% to $15 \%)$ and South ( $7 \%$ to $6 \%)$ regions, where prevalence was low. Hb levels according to gestational age were slightly higher in the first months of pregnancy and lower after the third or fourth months, depending on the reference used. Logistic regression analysis showed that group, geographic region, marital status, trimester of pregnancy, initial nutritional status, and prior pregnancy were associated with anemia $(\mathrm{p}<0.05)$.

CONCLUSIONS: Prevalence of anemia decreased after fortification, but remains high in the North and Northeast regions. Although fortification may have played a role in this favorable outcome, the contribution of other public policies implemented during the studied period should also be considered.

DESCRIPTORS: Pregnant Women. Anemia, Iron-Deficiency. Flour. Food, Fortified. Prenatal Care.

\section{INTRODUCTION}

Iron deficiency anemia is the most prevalent nutritional deficit globally. Although it affects all social strata and geoeconomic areas, it is associated with inadequate social and environmental conditions. ${ }^{3,11}$

Pregnant women are especially susceptible to iron deficiency anemia due to the increased iron requirements associated with rapid expansion of fetal tissues and production of red blood cells. ${ }^{20}$ The World Health Organization (WHO) estimates that over half the pregnant women in developing countries are anemic, while in developed countries anemia affects around one-quarter of pregnant women. ${ }^{23}$ Although national data for Brazil are not available, estimates indicate 
that frequency of anemia in the country is in the order of $30 \%$ to $40 \%{ }^{3}$ A recent review ${ }^{6}$ of articles published since the 1970's indicates that the available information on pregnancy-related anemia is scarce and shows wide geographical variability. However, the prevalences reported in this study are high. ${ }^{6}$

The deleterious consequences of pregnancy-related anemia include greater maternal and perinatal mortality, greater risk of preterm birth, and lower hemoglobin $\mathrm{Hb}$ levels in the newborn.

As an attempt to minimize the effects of anemia on mother and child health, the Ministry of Health has recommended iron supplementation in the second half of pregnancy since the 1980's, and, in 2005, implemented the National Program for Iron Supplementation, which reinforces this recommendation. ${ }^{a}$ Despite the apparent simplicity of this measure its effectiveness tends to be limited by a number of political, administrative, and planning/management factors, in addition to the interest and motivation of the pregnant woman herself. The adverse side effects of iron supplementation also affect adherence. These include nausea, vomiting, diarrhea, constipation, and abdominal pain. ${ }^{20}$

When a large fraction of the population is at high risk of becoming deficient for a specific micronutrient, universal food fortification is considered as the best alternative for intervention, as a complement to other strategies also aimed at improving the nutritional status of the population. ${ }^{24}$ Given the high and widespread prevalence of anemia across all social strata in Brazil, the federal government, in response to international recommendations and political will to minimize the effects of anemia among public health issues in the country, instituted the mandatory fortification of wheat and corn flour with iron, ${ }^{\mathrm{b}}$ which was implemented in July 2004. This strategy provides the highly promising perspective of a complementary source of iron to maintain adequate $\mathrm{Hb}$ levels and build iron reserves for periods of greater vulnerability.

Although a number of quasi-experimental studies carried out in Brazil have provided evidence of the efficacy of flour fortification in controlling anemia in children, 2,4,9,12,17,22 only very few studies evaluate the impact of nutritional programs in the field.

Thus, the aim of the present study was to compare prevalence of anemia and $\mathrm{Hb}$ levels among pregnant women before and after flour fortification with iron.

\section{METHODS}

This collaborative study, designed to evaluate the intervention using repeated cross-sectional panels, was carried out within public prenatal care services in 13 municipalities of the five Brazilian geographical regions: Northeast (Teresina, Recife, Salvador), North (Rio Branco, Belém, Manaus), Central-West (Cuiabá), Southeast (São Paulo, São Bernardo do Campo, Viçosa, Rio de Janeiro) and South (Maringá and Curitiba).

Retrospective data were obtained from medical records of pregnant women attending these facilities, divided into two groups: pre-fortification, comprising women who delivered before June/2004, and post-fortification, formed by women with date of last period after June/2005, at least one year after the implementation of the fortification strategy.

The minimum sample size for each group in each study site was calculated using the formula $n=Z \alpha^{2} P Q /$ $\mathrm{d}^{2}$, where $\mathrm{n}=$ minimum sample size; $\mathrm{Z}=$ confidence coefficient, which was set at 1.96 for an alpha of 0.05 ; $\mathrm{P}=$ prevalence; $\mathrm{Q}=$ complement of the prevalence $(\mathrm{Q}=1$ $\mathrm{P})$; and $\mathrm{d}=$ maximum error in absolute terms. Since there are no consistent estimates of the prevalence of anemia among Brazilian pregnant women, we assumed $\mathrm{P}=0.50$, equivalent to the highest relationship between $\mathrm{P}$ and $\mathrm{Q}$, and a precision of $\mathrm{d}=5 \%$. This yielded a sample size of $n=1.96^{2 *} 0.50 * 0.50 / 0.05^{2}=384$ women per group per study site. The final sample comprised 12,119 women, 6,062 in the pre-fortification group and 6,057 in the post-fortification group.

Data collection took place between 2006 and 2008 and included only low-risk pregnant women whose medical records included at least the $\mathrm{Hb}$ result and the date of first prenatal care visit, last period, and $\mathrm{Hb}$ testing. Sociodemographic data (age, education, marital status) and gynecological/obstetric and prenatal care history (weight and height at first visit, and number of previous pregnancies and prenatal care visits) were also obtained when available. Initial nutritional status was classified based on the woman's body mass index according to gestational age. $^{\mathrm{c}}$

$\mathrm{Hb}$ level data referred to the test performed at the time of the woman's first prenatal care visit. This was true also for women who began prenatal care during the second or third trimesters. We assumed that these women had not been oriented to use supplementation, which is recommended beginning at the $20^{\text {th }}$ week of pregnancy, given that they were not under prenatal care until that moment.

\footnotetext{
a Ministério da Saúde, Secretaria de Atenção à Saúde, Departamento de Atenção Básica. Manual operacional do Programa Nacional de Suplementação de Ferro. Brasília (DF); 2005.

${ }^{b}$ Ministério da Saúde, Agência Nacional de Vigilância Sanitária. Regulamento técnico para a fortificação das farinhas de trigo e das farinhas de milho com ferro e ácido fólico. Resolução RDC n 344, de 13 de dezembro de 2002. Diario Oficial Uniao, 18 dez 2002. [cited 3008 Jul 15]. Available from: http://e-legis.anvisa.gov.br/leisref/public/showAct.php?id=1679\&word=RDC

c Ministério da Saúde. Pré-natal e puerpério: atenção qualificada e humanizada - manual técnico. Brasília (DF): Ministério da Saúde; 2005.
} 
Gestational age at the time of $\mathrm{Hb}$ testing was calculated based on the date of last period and of the blood test. Pregnant women with $\mathrm{Hb}<11.0 \mathrm{~g} / \mathrm{dL}$ were considered anemic. $^{23}$

Taking into account the difficulty in diagnosing anemia during pregnancy due to hemodilution, ${ }^{20} \mathrm{Hb}$ values were evaluated according to gestational age, based on two different curves, published by the Centers for Disease Control and Prevention (CDC $)^{5}$ and by Szarfarc et al. ${ }^{21}$ The reason for using two references was the fact that the CDC curve ${ }^{5}$ is constructed based on European studies of pregnant women who received iron supplementation, which allows for comparisons of our data with those of other studies in the international literature, while the curve by Szarfarc et $\mathrm{al}^{21}$ is constructed based on data obtained from healthy but non-supplemented Brazilian pregnant women, and thus represents a setting closer to that of our sample.

We used SPSS version 11.0 software for data analysis. Anemia was defined as the dependent variable. Independent variables included group (pre- and postfortification); geographic region; age ( $<20$ and $\geq 20$ years); education (elementary and secondary/university); gestational trimester ( $\mathrm{I}=1-13$ weeks, $\mathrm{II}=14-27$ weeks, III=28 weeks or more); initial nutritional status (underweight, adequate weight, overweight/obese); number of previous pregnancies $(<2$ and $\geq 2)$ and of prenatal visits $(<6$ and $\geq 6$ ). Results were described using proportions and means, and independent variables associated with the occurrence of anemia were analyzed using the chi-square and Student's t tests.

Adjustment for potential confounders was done by logistic regression. To avoid the exclusion of potentially important variables, all variables associated with the outcome at $\mathrm{p}<0.20$ were included in multiple analysis. The introduction of each variable in the model was ordered by statistical significance, meaning that variables with lower $\mathrm{p}$-values were introduced first. To identify associations, we used a significance threshold of $5 \%(\mathrm{p}<0.05)$. The strength of the association between dependent and independent variables was evaluated using odds ratios (OR) both in univariate (crude OR) and multiple (adjusted OR) analysis. The
Hosmer \& Lemeshow test was used to determine goodness-of-fit.

The present study was approved by the Research Ethics Committee of the Universidade de São Paulo School of Nursing (Process no. 521/2006).

\section{RESULTS}

At least one year after the effective implementation of fortification, prevalence of anemia fell by 5.3 percentage points in the sample as a whole, a difference which was statistically significant $(\mathrm{p}<0.001)$ (Figure 1). However, there were important differences between regions. Significant reductions after fortification were detected both in regions in which initial prevalence was high, such as the Northeast (37.4\% to $28.7 \%$ ) and North $(32.2 \%$ to $24.9 \%)$, and in those in which initial prevalence was lower, such as the Southeast (18.3\% to $14.8 \%$ ).

Mean $\mathrm{Hb}$ levels were also significantly higher after fortification, both in the sample as a whole $(\mathrm{p}<0.001)$ and in the Northeast $(\mathrm{p}<0.001)$, North, and Southeast $(\mathrm{p}=0.002)$ regions (Table 1$)$.

Based on the CDC reference, Hb levels by gestational age in both groups were slightly higher during the first months of pregnancy, but lower after the fourth month (Figure 2). The same was initially true using as a basis the curve by Szarfarc et al, but after the third month of pregnancy mean $\mathrm{Hb}$ in the studied sample conformed to the curve.

Crude analysis of prevalence of anemia showed it to be associated $(\mathrm{p}<0.20)$ with the following variables: group (pre- and post-fortification), geographic region, marital status, age, education, trimester of pregnancy, number of prenatal care visits, initial nutritional status, and number of previous pregnancies. In multiple analysis, the selected variables remained significantly associated with the occurrence of anemia when compared to the reference category, with the exception of age, education, and number of prenatal care visits (Table 2).

Table 1. Mean (standard deviation) hemoglobin level before and after flour fortification. Brazil, 2002-2008.

\begin{tabular}{lccccc}
\hline Region & $\mathrm{n}$ & $\begin{array}{c}\text { Pre-fortification } \\
\text { mean (SD) }\end{array}$ & $\mathrm{n}$ & $\begin{array}{c}\text { Post-fortification } \\
\text { mean (SD) }\end{array}$ & $\mathrm{p}$ \\
\hline Brazil & 6,062 & $11.8(1.3)$ & 6,057 & $11.9(1.2)$ & $<0.001$ \\
Northeast & 2,137 & $11.3(1.1)$ & 1,718 & $11.6(1.2)$ & $<0.001$ \\
North & 678 & $11.5(1.2)$ & 911 & $11.7(1.1)$ & 0.002 \\
Central-West & 414 & $11.7(1.1)$ & 539 & $11.7(1.2)$ & 0.051 \\
Southeast & 2,085 & $12.1(1.2)$ & 2,088 & $12.2(1.1)$ & 0.002 \\
South & 748 & $12.7(1.1)$ & 801 & $12.6(1.1)$ & 0.774 \\
\hline
\end{tabular}




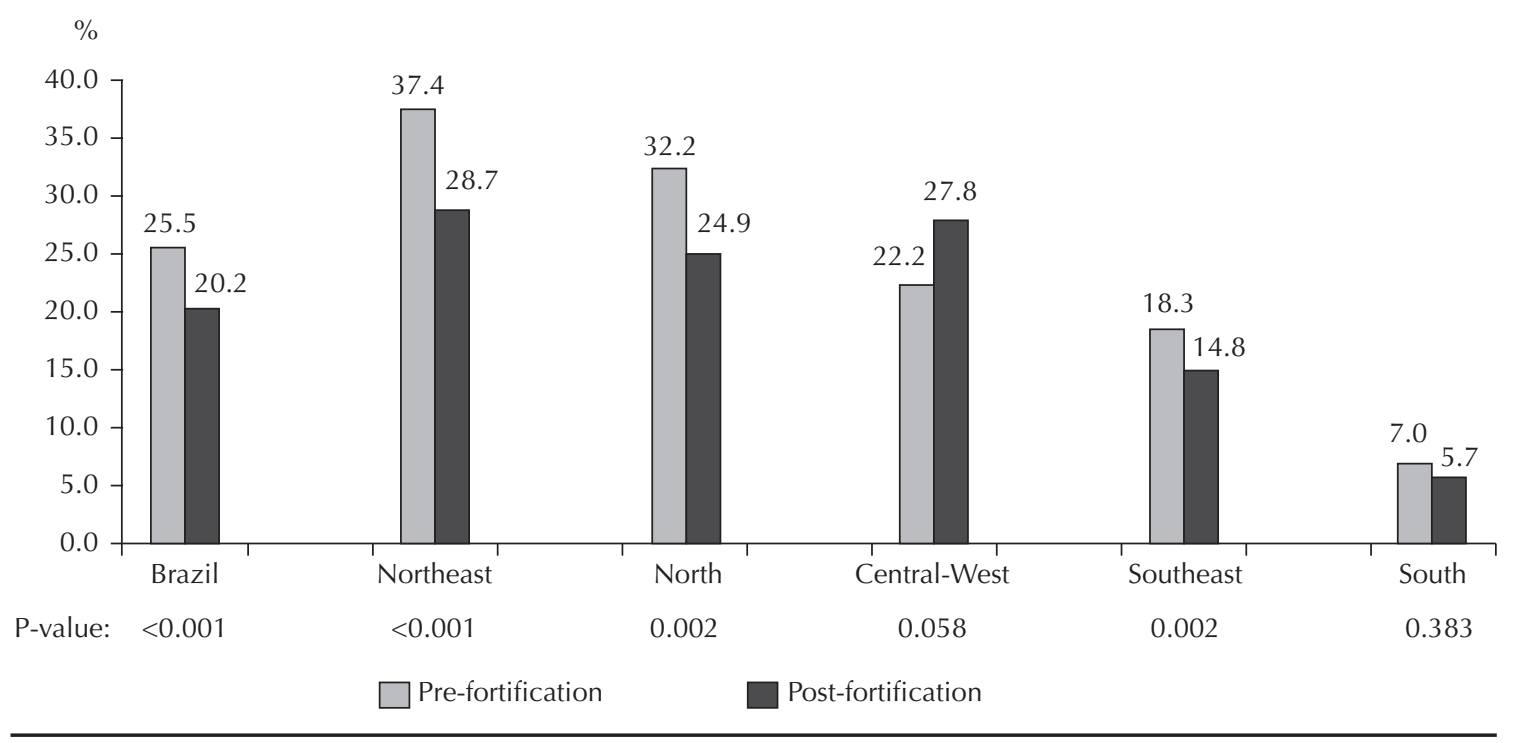

Figure 1. Prevalence of anemia among pregnant women (\%), before and after flour fortification. Brazil, 2002-2008.

\section{DISCUSSION}

For the sample as a whole (Brazil), prevalence of anemia was high, both before and after flour fortification. However, this was lower than the previously estimated $30 \%$ to $40 \%$ prevalence of anemia among Brazilian pregnant women. ${ }^{3}$ This degree of prevalence is considered as moderate epidemiological importance, as defined by the WHO (prevalence of anemia in pregnant women and schoolchildren between $20 \%$ and $40 \%){ }^{23}$ Important regional differences persist, as reported in other studies in the literature. ${ }^{6,11}$ Whereas prevalence was moderate in the North, Northeast, and Central-West regions, prevalence in the South and Southeast was low. Mean $\mathrm{Hb}$ levels were also significantly higher in the post-fortification group, both for the sample as a whole and for the Northeast, North, and Southeast regions.

Our results show that anemia prevalence was significantly lower after fortification in all regions except the Central-West. Prevalence in the entire sample fell by $5.3 \%$; however, in regions with higher prevalence, reductions were more marked: $8.7 \%$ in the Northeast, $7.3 \%$ in the North, $3.5 \%$ in the Southeast, and $1.3 \%$ in the South. In the Central-West, differences in some of the sociodemographic characteristics of the studied group may partly explain the increase in prevalence of anemia. Specifically, the post-fortification group contained a higher proportion of adolescents and women without a partner. However, these differences were controlled in logistic regression analysis, that is, marital status, which remained as a significant predictor was included in the multiple model as a control variable, prevalence of anemia therefore being adjusted for its effect.
A survey carried out in 2002 found that 31 countries in Latin America and the Caribbean had the necessary legislation in place to ensure the fortification of wheat and corn flour with micronutrients, including iron. ${ }^{8}$ In Brazil, although this measure was effectively implemented starting in July 2004, the Brazilian fortification program still lacks a regulatory foundation and procedures for monitoring and evaluating effectiveness, so as to provide information on the achievements of the program's goals. Evaluating the effect of the program is indispensable to allow for improvements in the current legislation.

Theoretically, programs and interventions targeting diseases should be evaluated with respect to goals determined a priori, during the planning stages. Certain designs are recommended in order to better evaluate the impact of interventions. ${ }^{13}$ However, if the frequency of the event prior to the implementation of the program is known, simply conducting a post-implementation survey allows one to evaluate its effectiveness.

In the case of anemia among pregnant women, prior studies are scarce, geographically localized, and based on small, restricted samples. ${ }^{6}$ Thus, the inexistence of solid data on anemia prior to the implementation of flour fortification prevented us from carrying out a simple post-implementation survey to evaluate the results of the fortification strategy. The evaluation of repeated cross-sectional panels used as a baseline the levels found prior to implementation.

Interventions such as food fortification yield results in the long term. However, experience shows that positive effects are larger and occur faster the greater the physiological need for the effects of the intervention. ${ }^{23}$ The choice of pregnant women to assess the effect of 
Table 2. Crude and adjusted analysis of the occurrence of anemia and its predictors, logistic regression model. Brazil, $2002-2008$.

\begin{tabular}{|c|c|c|c|c|c|c|c|}
\hline \multirow{2}{*}{ Variable } & \multirow{2}{*}{$\mathrm{N}$} & \multirow{2}{*}{$\begin{array}{c}\text { Anemia } \\
\mathrm{n}(\%)\end{array}$} & \multirow{2}{*}{$p^{*}$} & \multicolumn{2}{|c|}{ Univariate } & \multicolumn{2}{|c|}{ Multiple } \\
\hline & & & & OR Crude & $95 \% \mathrm{Cl}$ & OR Adjusted** & $95 \% \mathrm{Cl}$ \\
\hline Group & & & $<0.001$ & & & & \\
\hline Pre-fortification & 6,062 & $1,554(25.5)$ & & 1 & - & 1 & - \\
\hline Post-fortification & 6,057 & $1,224(20.2)$ & & 0.74 & $0.68 ; 0.81$ & 0.84 & $0.72 ; 0.98$ \\
\hline Geographic region & & & $<0.001$ & & & & \\
\hline Northeast & 3,855 & $1,293(33.5)$ & & 1 & - & 1 & - \\
\hline North & 1,589 & $445(28.0)$ & & 0.77 & $0.68 ; 0.88$ & 0.92 & $0.69 ; 1.22$ \\
\hline Central-West & 953 & $242(25.4)$ & & 0.67 & $0.57 ; 0.79$ & 1.09 & $0.78 ; 1.52$ \\
\hline Southeast & 4,173 & $690(16.5)$ & & 0.39 & $0.35 ; 0.44$ & 0.70 & $0.56 ; 0.89$ \\
\hline South & 1,549 & $98(6.3)$ & & 0.13 & $0.11 ; 0.17$ & 0.25 & $0.18 ; 0.34$ \\
\hline Marital status & & & 0.001 & & & & \\
\hline Partner & 5,820 & 1,336(23.0) & & 1 & - & 1 & - \\
\hline No partner & 2,925 & $766(26.2)$ & & 1.19 & $1.07 ; 1.32$ & 1.51 & $1.28 ; 1.77$ \\
\hline Age (years) & & & $<0.001$ & & & & \\
\hline$<20$ & 2,732 & 699(25.6) & & 1 & - & & \\
\hline$\geq 20$ & 9,271 & $2,045(22.1)$ & & 0.82 & $0.75 ; 0.91$ & & \\
\hline Education & & & $<0.001$ & & & & \\
\hline Elementary & 5,045 & $1,010(20.0)$ & & 1 & - & & \\
\hline Secondary/University & 3,942 & $1,012(25.7)$ & & 1.38 & $1.25 ; 1.52$ & & \\
\hline Trimester of pregnancy & & & $<0.001$ & & & & \\
\hline I & 5,096 & $582(11.4)$ & & 1 & - & 1 & - \\
\hline II & 5,358 & $1,529(28.5)$ & & 3.10 & $2.79 ; 3.44$ & 2.87 & $2.38 ; 3.46$ \\
\hline III & 1,665 & $657(39.5)$ & & 5.05 & $4.43 ; 5.76$ & 4.08 & $3.19 ; 5.23$ \\
\hline Number of prenatal care visits & & & $<0.001$ & & & & \\
\hline$<6$ & 1,895 & $397(20.9)$ & & 1 & - & & \\
\hline$\geq 6$ & 2,668 & $351(13.2)$ & & 0.57 & $0.49 ; 0.67$ & & \\
\hline Initial nutritional status & & & $<0.001$ & & & & \\
\hline Underweight & 2,080 & $591(28.4)$ & & 1 & - & 1 & - \\
\hline Adequate weight & 3,553 & $712(20.0)$ & & 0.63 & $0.56 ; 0.72$ & 0.79 & $0.66 ; 0.94$ \\
\hline Overweight/obesity & 1,735 & $226(13.0)$ & & 0.38 & $0.32 ; 0.45$ & 0.42 & $0.42 ; 0.66$ \\
\hline Previous pregnancies & & & $<0.001$ & & & & \\
\hline$\leq 2$ & 5,553 & $931(16.8)$ & & 1 & - & 1 & - \\
\hline$>2$ & 3,088 & $708(22.9)$ & & 1.48 & $1.32 ; 1.65$ & 1.61 & $1.36 ; 1.91$ \\
\hline
\end{tabular}

* Chi-square test for occurrence of anemia

* * Hosmer \& Lemeshow: $p=0.393$

fortification is therefore justified, since this is the group which has the highest demand for iron. Moreover, the study could only be carried out because the Brazilian health care system ensures prenatal care to all pregnant women within public services, and includes $\mathrm{Hb}$ testing as one of the recommendations for the first prenatal care visit. ${ }^{c}$ However, hematological alterations associated with pregnancy complicate the evaluation of anemia in this period, ${ }^{20}$ and therefore $\mathrm{Hb}$ levels were measured according to gestational age and compared with Brazilian and international curves.

In the present study, data were obtained from medical records. This can be regarded as a limitation given the quality of this information, which is not always standardized. However, use of secondary data allowed for an assessment of a large number of cases $(12,119$ pregnant women attending public health care facilities). Thus, it was possible to carry out a baseline survey of anemia in pregnant women and to determine its evolution at least one year after the effective implementation of flour fortification.

A bibliographical survey of studies published since the 1970's found that most studies of anemia prevalence in pregnant women in Brazil were carried out in the state of São Paulo, and that their results classify prevalence of anemia as moderate to severe. ${ }^{6}$ This suggests that the problem may be even greater in states that are less 

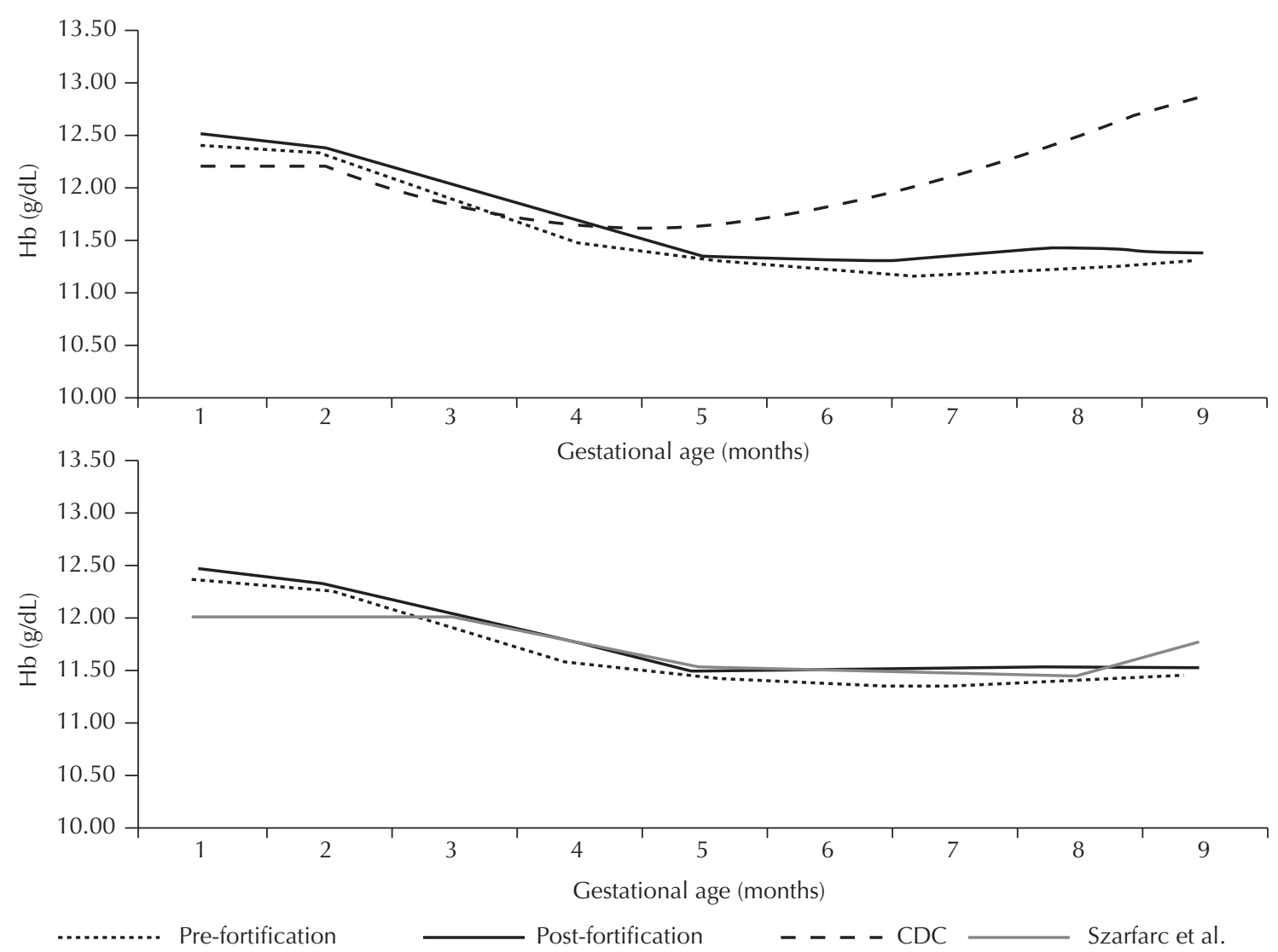

Figure 2. Mean hemoglobin level among pregnant women before and after flour fortification, according to CDC ${ }^{5}(1989)$ and Szafarc et $\mathrm{al}^{21}$ (1983) parameters and gestational age (months). Brazil, 2002-2008.

developed and have less access to health care services. The results of the present study, when analyzed by region, confirm this possibility.

In addition to the social, economic, and cultural differences between the Brazilian regions, there are also differences in the quality of prenatal care. While only $1.4 \%$ of mothers in the South and Southeast do not have access to prenatal care, over half of them having seven or more visits, in the North, $6.4 \%$ of births occur without prenatal care, and only $28 \%$ of women have seven or more visits. ${ }^{\mathrm{d}}$

Despite the positive experiences with food fortification reported in North America and Western Europe, iron deficiency continues to be a public health issue in certain population groups in these countries - such as women reproductive age with excessive menstrual blood loss and pregnant women - who cannot fulfill their large requirement for the mineral only through dietary intake. ${ }^{19}$

Few population-based studies have been carried out to measure the effect of fortification, most of which among children. The most compelling data refers to studies of the fortification of infant formula in the United States, which reduced anemia prevalence from $7.8 \%$ in 1975 to $2.9 \%$ in 2984 among low-income children under age two years. ${ }^{19}$ In Venezuela, where wheat and corn flour fortification was implemented in 1993, a study carried out with a small group of children showed a reduction from $37 \%$ to $15 \%$ in prevalence of iron deficiency and from $19 \%$ to $10 \%$ in prevalence of anemia. ${ }^{15}$ In Mexico, flour fortification with iron contributed towards a reduction in prevalence of anemia from $27.5 \%$ to $7.7 \%$ among preschool children and from $18.5 \%$ to $7.6 \%$ among schoolchildren. ${ }^{14}$ In Chile, iron deficiency anemia was controlled by a national program for the fortification of flour with iron which began in the 1950 's. This strategy, complemented by fortification of milk, reduced prevalence of anemia from $29 \%$ to $9 \%$ among children under two years of age, although prevalence is still $20 \%$ among pregnant women in the second and third trimesters of pregnancy. ${ }^{18}$

In Brazil, evaluations of flour fortification, also carried out mostly among children, show discrepant results. In Pelotas, Southern Brazil, in spite of the high prevalence of anemia ( $30.2 \%$ to $41.5 \%)$, no effect of fortification

d Ministério da Saúde. Saúde Brasil 2006: uma análise da desigualdade em saúde. Brasília (DF); 2006. 
was detected among children under six years of age, which was justified partially by the insufficient intake of flour and/or by the low bioavailability of the iron added as a supplement. ${ }^{1}$ However, children aged 24-60 months seen at child education centers in the city of São Paulo evaluated after flour fortification showed significantly lower prevalence of anemia when compared to prior studies conducted in the same region, allowing the authors to suggest that the iron supplements contained in fortified foods have had a positive effect. ${ }^{7}$

There are practically no studies of the impact of food fortification on pregnant and reproductive-age women. One example is the reduction in the prevalence of anemia among Swedish reproductive-age women, from $25 \%$ in the 1960 's to $7 \%$ in the following decade. ${ }^{19} \mathrm{In}$ Brazil, there no nationwide data is available on the prevalence of anemia in women of reproductive age prior to flour fortification. However, the Pesquisa Nacional de Demografia e Saúde da Criança e da Mulher (PNDS, National Survey of Health and Demographics of Children and Women), carried out in 2006, ${ }^{\mathrm{e}}$ that is, two years after the effective implementation of flour fortification, found high prevalence of anemia (29.4\%). As for pregnant women, a single study carried out in a prenatal care facility within university hospital ${ }^{\mathrm{f}}$ found a significant reduction in frequency of anemia, from $28.9 \%$ to $7.9 \%$ one year after the implementation of fortification. According to Côrtes, although variables that were not investigated could have contributed towards such a result, mandatory fortification was essential given the finding of a significant increase in iron intake after fortification.

In the present study, pregnant women in both groups started pregnancy with $\mathrm{Hb}$ levels that were higher than reference values. However, in the second half of pregnancy, $\mathrm{Hb}$ values fell below CDC parameters. ${ }^{5}$ Such a difference may be related to supplementation, since our subjects had not yet been given iron sulfate supplementation at the time of $\mathrm{Hb}$ testing. The finding that the curve in our sample followed the reference by Szarfarc et $\mathrm{al}^{21}$ after the third month of pregnancy corroborates the previous hypothesis, since the latter curve was built on data obtained from Brazilian pregnant women not under iron supplementation. This reiterates the importance of pharmacological supplementation for the maintenance of normal $\mathrm{Hb}$ levels.

Regarding the determinants of anemia, pregnant women in the post-fortification group were $16 \%$ less likely to be anemic. Theoretically, this result was expected, in light of the positive experiences obtained with iron fortification in industrialized nations. ${ }^{19}$
Almost half of the pregnant women underwent $\mathrm{Hb}$ testing during the first trimester of pregnancy, a period in which expansion of volemia and increased need for iron by fetus and placenta are not yet significant. ${ }^{20} \mathrm{This}$ justifies the finding that pregnant women in the first trimester are at lower risk of becoming anemic, given that the same cutoff level of $\mathrm{Hb}$ was used for diagnosis. In addition to advanced gestational age, other variables associated with anemia were low initial weight and two prior pregnancies, which are in agreement with the results of other investigations. ${ }^{10}$

Women without a partner were $50 \%$ more likely to be anemic than those with a partner, and women from the Southeast and South regions were $30 \%$ and $75 \%$ less likely to be anemic than those from the Northeast. Results from the PNDS survey ${ }^{\mathrm{e}}$ show that the North and Northeast concentrate the worst living conditions in the country, in spite of the migration of a proportion of the very poor population to higher classes and of the benefits brought by social programs.

Social insertion influences access to food, nutritional education, and the quality of the diet. Therefore, occurrence of anemia is still linked to adverse social and economic conditions, be it through qualitative or quantitative deficiencies in diet, or through the precariousness of environmental sanitation, a condition that is typical of areas inhabited by the lower social classes in Brazil. ${ }^{16}$

It is therefore important to emphasize the point that prevention and control of anemia must follow an integrated, multidisciplinary and long-term approach, in coordination with other nutritional and health care programs and with other sectors of society, taking the form of an intersectorial nutritional intervention policy. Furthermore, a permanent monitoring system is indispensible to identify the evolution of the anemia problem in response to the various strategies that are implemented. A practical and efficient way to monitor this would be to include this data in the Brazilian health information system, so as to allow for adequate follow-up of pregnant women enrolled in the Programa de Humanização no Pré-Natal e Nascimento (SISPRENATAL, Program for Humanization of Prenatal and Delivery Care), of the Brazilian National Health Care System.

Prevalence of anemia remains high in the Northeast, North, and Central-West regions. However, the reduction in prevalence in the sample as a whole suggests that food fortification is an important approach. It should be noted that variables that were not investigated - including macroeconomic policies and other public policies that were expanded in the period,

\footnotetext{
e Ministério da Saúde. Pesquisa Nacional de Demografia e Saúde da Criança e da Mulher - PNDS 2006: dimensões do processo reprodutivo e da saúde da criança. Brasília (DF); 2009.

${ }^{f}$ Côrtes MH. Impacto da fortificação das farinhas com ferro nos níveis de hemoglobina das gestantes atendidas pelo pré-natal do Hospital Universitário de Brasília [master's dissertation]. Brasília (DF): Universidade de Brasília, Faculdade de Ciências da Saúde, Departamento de Nutrição; 2006.
} 
such as the Estratégia Saúde da Família and the Bolsa-Família - may have contributed towards such an improvement. It is recommended, therefore, that further studies be conducted which include the permanent monitoring of the situation with regard to anemia during pregnancy.

\section{REFERENCES}

1. Assunção MCF, Santos IS, Barros AJD, Gigante DP, Victora CG. Efeito da fortificação de farinhas com ferro sobre anemia em pré-escolares, Pelotas, RS. Rev Saude Publica. 2007;41(4):539-48. DOl:10.1590/S003489102006005000031

2. Bagni UV, Baião MR, Santos MMAS, Luiz RR, Veiga GV. Efeito da fortificação semanal do arroz com ferro quelato sobre freqüência de anemia e concentração de hemoglobina em crianças de creches municipais do Rio de Janeiro, Brasil. Cad Saude Publica. 2009;25(2):291-302. DOI:10.1590/S0102311X2009000200007

3. Batista Filho M, Souza AI, Bresani CC. Anemia como problema de saúde pública: uma realidade atual. Cienc Saude Coletiva. 2008;13(6):1917-22. DOI:10.1590/S1413-81232008000600026

4. Beinner MA, Lamounier JA, Tomaz C. Effect of ironfortified drinking water of daycare facilities on the hemoglobin status of young children. J Am Coll Nutr. 2005;24(2):107-14.

5. Centers for Diseases Control and Prevention. Current trends CDC criteria for anemia in children and childbearing-aged women. MMWR Morb Mortal Wkly Rep. 1989;38(22):400-4.

6. Côrtes MH, Vasconcelos IAL, Coitinho DC. Prevalência de anemia ferropriva em gestantes brasileiras: uma revisão dos últimos 40 anos. Rev Nut. 2009;22(3):40918. DOI:10.1590/S1415-52732009000300011

7. Costa CA, Machado EH, Colli C, Latorre WC, Szarfarc SC. Anemia em pré-escolares atendidos em creches de São Paulo (SP): perspectivas decorrentes da fortificação das farinhas de trigo e de milho. Nutrire Rev Soc Bras Aliment Nutr. 2009;34(1):59-74.

8. David LFJ. Fortificación de harina de trigo en América Latina y región del Caribe [carta ao editor]. Rev Chil Nutr. 2004;31(3):336-47. DOI:10.4067/S071775182004000300009

9. Dutra-de-Oliveira JE, Marchini JS, Desai I. Fortification of drinking water with iron: a new strategy for combating iron deficiency in Brazil. Am J Clin Nutr. 1996;63(4):612-4.

10. Ferreira HS, Moura FA, Cabral Júnior CR. Prevalência e fatores associados à anemia em gestantes da região semi-árida do Estado de Alagoas. Rev Bras Ginecol Obstet. 2008;30(9):445-51. DOI:10.1590/S010072032008000900004

11. Fujimori E, Sato APS, Araújo CRMA, Uchimura TT, Porto ES, Brunken GS et al. Anemia em gestantes de municípios das regiões Sul e Centro-Oeste do Brasil Rev EsC Enferm USP. 2009;43(Spec No 2):1204-9. DOI:10.1590/S0080-62342009000600011

12. Giorgini E, Fisberg M, de Paula RA, Ferreira AM, Valle J, Braga JA. The use of sweet rolls fortified

with iron bis-glycinate chelate in the prevention of iron deficiency anemia in preschool children. Arch Latinoam Nutr. 2001;51(1 Suppl 1):48-53.

13. Habicht JP, Victora CG, Vaughan JP. Evaluation designs for adequacy, plausibility and probability of public health programme performance and impact. Int J Epidemiol. 1999;28(1):10-8. DOI:10.1093/ije/28.1.10

14. Jyväkorpi SK, Martínez H, Pineda A, Pizarro $\mathrm{S}$, Monárrez-Espino J. Iron nutrition in schoolchildren of western Mexico: the effect of iron fortification. Ecol Food Nutr. 2006;45(6):431- 47. DOI:10.1080/03670240600985233

15. Layrisse M, Chaves JF, Mendez- Castellano H, Bosch V, Tropper E, Bastardo B, et al. Early response to the effect of iron fortification in the Venezuelan population. Am J Clin Nutr. 1996;64(6):903-7.

16. Martins IS, Alvarenga AT, Siqueira AAF, Szarfarc SC, Lima FD. As determinações biológica e social da doença: um estudo de anemia ferropriva. Rev Saude Publica. 1987;21(2):73-89. DOI:10.1590/S003489101987000200003

17. Miglioranza LHS, Matsuo T, Caballero-Córdoba GM, Dichi JB, Cyrino ES, Oliveira IBN, et al. Effect of long-term fortification of whey drink with ferrous bisglycinate on anemia prevalence in children and adolescents from deprived areas in Londrina, Paraná, Brazil. Nutrition. 2003;19(5):419-21. DOI:10.1016/ S0899-9007(02)00933-4

18. Olivares M, Pizarro F, Hertrampf E, Walter T, Arredondo M, Letelier A. Fortificación de alimentos con hierro en Chile. Rev Chil Nutr. 2000; 27(3):340-4.

19. Ramakrishman U, Yip R. Experiences and challenges in industrialized countries: control of iron deficiency in industrialized countries. J Nutr. 2002;132(4 Suppl):820S-4S.

20. Souza Al, Batista Filho M, Ferreira LOC. Alterações hematológicas e gravidez. Rev Bras Hematol Hemoter. 2002;24(1):29-36. DOI:10.1590/S151684842002000100006

21. Szarfarc SC, Siqueira AAF, Martins IS. Avaliação da concentração de ferro orgânico em uma população de grávidas. Rev Saude Publica. 1983;17(3):200-7. DOI:10.1590/S0034-89101983000300002

22. Vítolo MR, Aguirre ANC, Kondo MR, Giuliano Y, Ferreira N, Lopez FA. Impacto do uso de cereal adicionado de ferro sobre níveis de hemoglobina e a antropometria em pré-escolares. Rev Nutr. 1998;11(2):163-71. DOI:10.1590/S141552731998000200007

23 World Health Organization. Iron deficiency anaemia: assessment, preventing, and control: a guide for programme managers. Geneva; 2001. 
24. World Health Organization. Guidelines on food fortification with micronutrients. Geneva; 2006.
25. Zimmermann MB, Hurrell RF. Nutritional iron deficiency. Lancet. 2007;370(9586): 511-20. DOI:10.1016/S0140-6736(07)61235-5

Authors (continuation):

Ilma Kruze Grande de Arruda (Departamento de Nutrição. Centro de Ciências da Saúde. Universidade Federal de Pernambuco. Recife, PE, Brasil); Taqueco Teruya Uchimura (Departamento de Enfermagem. Centro de Ciências da Saúde. Universidade Estadual de Maringá. Maringá, PR, Brasil); Gisela Soares Brunken (Departamento de Saúde Coletiva. Instituto de Saúde Coletiva. Universidade Federal do Mato Grosso. Cuiabá, MT, Brasil); Lucia Kiyoko Ozaki Yuyama (Instituto Nacional de Pesquisas da Amazônia. Manaus, AM, Brasil); Pascoal Torres Muniz (Departamento de Ciências da Saúde e Educação Física. Centro de Ciências da Saúde e do Desporto. Universidade Federal do Acre. Rio Branco, AC, Brasil); Silvia Eloiza Priore (Departamento de Nutrição e Saúde. Centro de Ciências Biológicas e da Saúde da Universidade Federal de Viçosa. Viçosa, MG, Brasil); Maria Alice Tsunechiro (Departamento de Enfermagem em Saúde Materno-Infantil e Psiquiátrica. Escola de Enfermagem. USP. São Paulo, SP, Brasil); Andréa das Graças Ferreira Frazão (Departamento de Nutrição. Faculdade de Nutrição. Universidade Federal do Pará. Belém, PA, Brasil); Cynthia R Matos Silva Passoni (Curso de Nutrição. Faculdades Integradas do Brasil. Curitiba, PR, Brasil); Claudia Regina Marchiori Antunes Araújo (Programa de Pós-Graduação em Enfermagem. Escola de Enfermagem. USP. São Paulo, SP, Brasil). Research supported by Conselho Nacional de Desenvolvimento Científico e Tecnológico (CNPq -Process no. 402295/2005-6). The authors declare that there are no conflicts of interests. 